\title{
Sinematik Kurgunun Bilinçaltı Mekânları-Tekinsiz Mekânlar
}

\author{
Mine TUNÇOK SARIBERBEROĞLU ${ }^{1 *}$
}

Öz

Zamanı ve mekânı kullanarak yeni bir gerçeklik oluşturmaya çalışan sinema, mekânın ve onun temsillerinin kavramsallaştırılması aracılığı ile varoluşsal deneyim ortamları sağlamaktadır. Gündelik hayattan aşina olduğumuz pek çok durum sinema tekniklerinin -tekrar eden kurgular, biçimsel manipülasyonlar- kullanımının yanı sıra doğrudan mimari mekândan -klostrofobik mekânlar, sonu gözükmeyen koridorlar vs. - beslenerek gerilim unsurunu ön plana çıkabilmektedir. Bu noktada gerilim sineması mekânları kullandığı psikolojik alt metinler ile mekân-deneyim araştırmaları için zengin ortamlar oluşturmasının yanı sıra bu kavramların mekânsallaşma biçimlerinin irdelenmesi ile de mimari söyleme olanak sağlamaktadır. Fantastik/korku-gerilim sinemasının temelinde yer alan tekinsizlik olgusu bilinç kavramı ile ilişkilendirilmekte ve 'aşina olduğumuz bir şeyin içinde yatan rahatsız edicilik' tanımlamasına dayanmaktadır. Bu filmlerde de oluşturulmaya çalışılan mekânsal tekinsizlik mimari mekânın konu edindiği en tanıdık olan ev kavramından insan zihninin bilinçaltı rüya mekânlarına kadar geniş bir yelpazede varlık göstererek, sinema anlatımının derinleşmesine olanaklar sağlamaktadır. Bu bağlamda mekân, sinema ve psikoloji arakesitinde yer alan çalışma mekân ve temsil ilişkisine tekinsizlik kavramı üzerinden yaklaşmaktadır. Çalışma kapsamında olay örgüsünün ağırlıklı olarak tanımlı kurgusal mekânlar üzerinden gerçekleştiği fantastik/korku-gerilim türünde seçilen bir grup film aracılığıyla, tekinsizlik kavramının tanımı ve bu bağlamda sinemada "tekinsizlik" hissinin yaratılmasında öne çıkan psikolojik biçimlerin mekânsal yansımalarının bilinç, bilinçaltı ve bilinçdışı kavramları üzerinden irdelenmesi amaçlanmaktadır.

Anahtar Kelimeler: Sinema, Mekân, Psikoloji, Tasarım, Tekinsizlik

\section{Subconscious Spaces in Cinematic Environments- Uncanny Spaces}

\begin{abstract}
\footnotetext{
${ }^{1}$ Mimar, Dr./Architect, PhD.

* Illgili yazar/Corresponding author: minetuncok@gmail.com

Gönderim Tarihi / Received Date: 11.11.2019

Kabul Tarihi / Accepted Date: 08.06.2020
}

Cinema tries to create a new reality by using time and space, and offers experience of existential environments through the conceptualization of space and its representations. In cinema, many situations that are familiar from everyday life can be a medium of tension directly from architectural spaces such as well as cinematic techniques. At this point, cinema spaces not only create environments for spaceexperience researches with the psychological sub-texts, but also enable architectural discourse to examine the spatial parameters of these concepts. As a psychological term; the phenomenon of uncanny, which lies at the basis of the fantastic / horrorthriller cinema, is associated with the concept of consciousness and is based on the definition of 'disturbing underlying something we are familiar with'. The spatial uncanny that is attempted to be created in films provides endless possibilities for the deepening 
of cinematic expression by presenting a wide range from the most familiar house concept to human mind itself to subconscious dream spaces. In this context, the phenomenon of uncanny is discussed through the concepts of consciousness, subconscious and unconscious and spatial forms of these concepts in cinema are examined through selected films.

Keywords: Cinema, Space, Psychology, Design, Uncanny

\section{GiRiş}

Mekân; farklı disiplinlerce çeşitli yaklaşımlar doğrultusunda ele alınan ve her defasında içerisine yeni yeni anlamlar yüklenen bir kavram olarak karşımıza çıkmaktadır. İnsanoğlu var olduğundan bugüne etrafındaki boşluğu tanımlamak için arayış içerisindedir. Kimi zaman doğayı taklit ederek kimi zaman da karşı koyarak kendine ait bir yer oluşturma çabası en temel mekân kavramına karşılık gelmektedir. Kendine ait bir yer kavramı olarak mekânı kişinin varoluş deneyiminin bir parçası olarak ele almak mümkündür. Ponty, Mekânın Fenomenolojisi kitabında mekânın varoluşsal bir durum olduğunu vurgular (Merleau-Ponty,1962, s. 293). Onun deyimiyle mekân varoluşsal olduğu gibi aynı zamanda "varoluş da mekânsaldır." Varoluş içsel bir zorunluluk ile 'dışa' açılır, böylece zihinsel bir mekândan ve anlamlar dünyasından bahsetmek mümkündür.

Zihinsel ve fiziksel mekân ilişkisinin ara kesitinde yer alan ve varoluşun çeşitli temsillerini üreten sinema ise kullandığı imgeler ile mekân kurgusunu manipüle ederek izleyiciye ulaşmayı hedefler. Sinema anlatısı imgeler ve mekânsal kurgular ile deneyime dayalı bir etkileşim oluşturur. Bir sinema ürünü deneyimlenirken izleyicinin zihninde canlananların tümü imgelerden oluşur. Sinemasal anlatımda ışık, gölgeleme, karşıtık, açılar, çerçeveler, tonlamalar, müzik gibi öğelerle mekânsal kurgular örgütlenerek yönetmen tarafından tamamen kendi denetiminde algılanan bir film mekânı yaratılır ve izleyicinin deneyimi böylece yönlendirilir (Beşışık, 2013, s. 3).

Korku-gerilim filmleri; mekânsal kurgunun tehdit unsurları ile bezendiği, film karakterlerinin bilinçaltı durumlarının sorgulandığı bir anlatım diline sahiptir (Kılıç, 2017, s. 429). Bilimkurgu filmlerinin de dahil edilebileceği fantastik ya da korku içeren gerilim filmlerinde mekân kavramı bilinç, bilinçaltı gibi kavramlar ile oynayarak oluşturulan atmosfer üzerinden izleyiciye ulaştırmaktadır. Mekânlar genelde sıra dışı, tenha, karanlık, sisli veya yabancı ortamlar üzerinden kurgulanırken sıradan, aşina ortamlar üzerinden de korku unsurunu izleyiciye aktaran öğeler barındırabilmektedir. Büyük evler, şatolar, deniz, orman ya da uzayın derinlikleri gibi sınırsız alanların yanı sıra kalabalık şehirler içerisinde dar labirentvari sokaklar, sıradan ev ortamları ya da her gün içinde bulunabileceğimiz kamusal alanlar bir anda tekinsiz mekânlara dönüşebilmektedir. Bu noktada Freud'un tekinsizlik kavramı karşımıza çıkar (2003, s. 124). Birey aşina olduğu bir durumu/olayı tanımlayamadığı ya da ona yabancılaşmaya başladığı anda tekinsizlik oluşur. Freud'un temellendirdiği "aşina olanın tekinsizliği" tam olarak bu tür filmler üzerinden izleyiciye ulaşmakta ve sinemasal mekânı tanıdık olan ev mekânı üzerinden insan zihninin içine kadar bilinç ve bilinçaltı kavramlarının üzerinden sorgulamaya olanak sağlamaktadır.

Çalışma psikolojik bir kavram olan tekinsizlik olgusunun gerilim sinemasındaki mekân temsillerine odaklanmaktadır. Bu noktada çalışma kapsamında ikinci bölümde "tekinsizlik" üzerinden bilinç, bilinçaltı ve bilinçdışı kavramları irdelenmekte ve alt başlıklar içinde mekân temsillerinin bu kavramlar doğrultusunda sinema filmleri üzerinden örneklendirildiği bir yöntem izlenmektedir. İrdelenen filmler senaryo ve 
kullandıkları sinematik atmosferler göz önünde bulundurularak bilinç, bilinçaltı ve bilinç dışı kavramlarının mekânsal ve kavramsal karşılıkları doğrultusunda belirlenmiştir. Çalışma içeriğinde filmlerin yer alış sırası bilindik fiziksel mekânın bilinç ile ilişkisinden başlayarak bilinçaltı mekân kurgularına ve insan zihninin içindeki bilinçdışı mekânlara doğru şekillenmektedir. Sinematik mekân kurgusunun tekinsizlik kavramı üzerinden okunmasına olanak sağlayan çalışma; mekân, psikoloji ve sinema üçgeninde bir arakesitte yer almakta ve bu alanda gerçekleştirilebilecek başka çalışmalar için de örnek niteliği taşıması amaçlanmaktadır.

\section{BíLINÇ, BÍLINÇALTI, BILINÇDIŞI'NIN TEKINSIZLIG̈i}

Genel olarak, "insanın nesnel dünyayı ve kendi kişisel varlığını anlamasına etkin biçimde katılan zihinsel süreçlerin toplamı (Frolog ve diğ., 1997, S. 59) olarak tanımlanan bilinç kavramı bireysel (psikolojik) ve toplumsal (sosyolojik) olarak ikiye ayrılmaktadır. Bireysel bağlamda ele alındığında da çoğu kez "psişik" kavramı ile eş anlamlı kullanılan ve psikolojik bağlamda "algı ve bilgilerin anlıkta duru ve aydınlık olarak izlenme süreci" olarak tanımlanan (Enç, 1974, s. 19) bilincin en temel özelliği Zijderveld'e (1985) göre kişiyi kendi varlığının farkındalığına sahip kılmasıdır (Aytaç, 2003 , s. 10). Temel olarak psikoloji ve psikanalizde ele alınan ve genel olarak "farkında olma hali" olarak tanımlanan (Shaffer, 1991, s. 26; Bruno, 1982, s. 56) bilinç kavramı içerisinde duyum, duygu, algı kavramlarının ele alınması bu kavramın farklı disiplinler tarafından da farklı perspektiflerde ele alınmasına olanak sağlamaktadır.

Psikanalitik ekol tarafından psikolojik yaklaşımların temeline yerleştirilen bilinçlilik hali için uyanıklık ve farkında olma yeterli değil aksine zihinsel süreçlerin gerçeğe uygun, neden-sonuç ve yer, zaman bağlantılarını da gözeten mantıklı işlemler olmaları gereklidir (Ornstein, 1990, s. 206). Bu ekole yön veren en önemli isim olan Freud'a göre zihinsel süreçler bilinçdışı, bilinçaltı ve bilinç olmak üzere en derinden yüzeye doğru ilişkilenen bir yapılanma gösterirler (Ornstein, 1990, s. 207). Bütünüyle farkına varılan süreçlerin yer aldığı bilinç zihnin en üst fakat en küçük katmanıdır. Bilinçaltı ise anı ve yaşantıların bilinçli bir çaba ile ve bazı zamanlar kendiliğinden fark edilebilir hale gelmesi olarak tanımlanmaktadır. Bununla birlikte zihinsel süreçlerin en derininde yer alan bilinçdışında ise hiçbir mantık ve kural geçerli değildir, "bilinçdışında yerleşmiş olan istek, dürtü, anı ve yaşantılar sözle ifade edilemezler, kısmen sanat ürünlerinde kendilerini açığa vurabilirler (Ornstein, 1990, s. 207).

Bu aşamada devreye giren tekinsizlik kavramını bilinç ile ilişkilendirerek ele alan Freud, bu durum için Almanca "unheimlich" kelimesini kullanmaktadır. Freud'a göre Türkçeye tekinsiz, İngilizceye uncanny olarak çevirilen kelime tanıdık, bildik, yerli-evle ilgili anlamlarına gelen "heimlich" kelimesinin zıttıdır (Freud, 2003, s. 124). Eve ait ev ile ilgili anlamına gelen "heim" kelimesinden türeyen kavramdaki tekinsizlik Freud'a göre yeni bir şeyin yarattığı heyecandan ziyade, önceden bilindiği varsayılan aşina olunan bir şeyin ya da durumun kazandığı yabancılık niteliğinden doğan bir yeniden algılayıştır. Tanıdık, bildik olanın bilinçaltında bastırılan bazı sebepler ile geri dönmesiyle yüzeye çıkan korku ve kaygının tekinsizlik oluşumuna neden olduğunu vurgulayan Freud zihinsel belirsizlikten çok daha önce bilinen bir şeyin tuhaflaşması, anlamsız bir biçimde yabancılaşması sonucu hissedilen korkunun endişe ve belirsizlik yarattığını vurgulamaktadır (Freud, 2003, s.124).

Bu noktada tekinsizlik kavramını Heidegger'in "dünya içinde var olma"-dasein kavramı üzerinden ele almak olasıdır. İnsan günlük deneyimler doğrultusunda kendi kendisini yorumlayan ve anlamlandıran bir varlıktır. Kavramın temelinde mekân, bir etkileşim ve deneyim yeri olarak ele alınır ve bu kavram doğrultusunda da insanın yer ile olan 
ilişkisini anlamamız mümkündür. Bu fenomenolojik yaklaşım doğrultusunda mekâna bakış mekânın dünyanın bütünü ya da deneyimleyen kişi için önemini ortaya koyan, deneyimi anlamaya çalışan bir bakış açısıdır (Heidegger, 1996, s. 33). Ona göre insan dünyada varolur; insanoğlu içinde yaşadığı dünyada var iken, bu dünyanın kurulumu da insanın kendi deneyimlerinden oluşur (1996, s. 150-151).

Sinemasal mekânda tekinsizlik kavramının bu var olma noktasında ortaya çıktığını söylemek mümkündür. Kişinin en bildik en aşina olduğu durum kendisinin varoluş biçimi iken bu kavramın sarsılması en temel tekinsizlik hissinin oluşması olarak ortaya çıkar. Bu noktada sinemada bilinç, bilinçaltı ve bilinçdışı durumlar varoluş kavramını mekânsallaştırarak izleyiciye ulaşır. Bu mekânlarda bilindik ev kurgusundan insan zihninin derinliklerine gönderme yapılan labirentvari mekânlara, hatta doğrudan insan zihninin içinden varoluşa dair tekinsiz mekânsal örüntülere rastlamak mümkündür..

\subsection{Bilinç Mekânı; Ev’in Tekinsizliği- Aşina Olanın Yabancılaşması}

Varoluşun en temeline baktığımızda ev kavramı karşımıza çıkar. Ev bize hem dağınık imgeler hem de imgeler bütünü sunar (Bachelard, 2003, s. 33). Bachelard'a göre ev öz varlığımızın ana mekânıdır. İçimizde yalnızca anılarımız değil, unuttuklarımız barınmaktadır. Bilinçsizliğimiz barındırılmıştır. Ruhumuz bir oturma yeridir ve evleri, odaları sürekli anımsayarak kendi içimizde oturmayı öğreniriz. Bu noktada ele alınabilecek olan klasik "lanetli ev“ öykülerindeki ıstırap çeken mekânlar adeta insan zihninin gizli bölümlerini açığa çıkarma işlevi görürler.

Kişinin varlığı ile bütünleşen ev kavramını bilinç kavramı ile ilişkilendirmek mümkündür. Bütünüyle farkına varılan süreçlerin yer aldığı bilinç; bizim evimizdir. Kendimizin farkında olduğumuz, deneyimler oluşturarak var olduğumuz en temel mekân olan "ev" Bachelard'a (2003, s. 36) göre, düşünceler, anılar ve düşler için en büyük birleştirici güçlerden biridir ve insan ruhunun çözümleme aracı olarak ele alınabilir. Beden ve ev tasarımları arasında düş yorumlarında benzerlik kuran Freud'a göre ev, hem en tanıdık, güvenli olandır, hem de içinde sırlar barındırır: hem tekin, hem de tekinsizdir (Freud, 2003). Bu bağlamda tekinsizlik kavramını "ev" ekseninde çeşitli olayları ve psikolojik durumları bilinç, bilinçdışı ve bilinçaltı durumlarından yararlanarak yarattığı atmosferle seyirciye yaşatan, onu imgeler dünyasında gezdiren sinema üzerinden ele almak mümkündür. Mimarinin en önemli bileşenlerinden mekânı kullanan sinema aşinalık hissi üzerinden ev kavramını kullanarak tekinsizlik hissi oluşturabilmekte, bilinen ev kavramını fiziki uzay ve zamanın sınırlarından bağımsız bir şekilde yeniden kurgulayabilmektedir.

Başka bir ifadeyle bir insanın mekânı benimsemesi için onunla tinsel bir etkileşim içinde olması gerekir. Bu düşünceye örnek olarak senaryosunu ve yönetmenliğini Alejandro Amenábar'ın gerçekleştirdiği 2001 yapımı The Others/Diğerleri filmindeki kurgu ele alınabilir (Şekil 1). Filmde kendisini ailesine adamış ve ailesini bir arada tutmaya çalışan bir kadının filmin merkezinde yer alan "ev mekânı" ile ekrana yansıyan barınma/var olma temelli bir ilişki söz konusudur. 


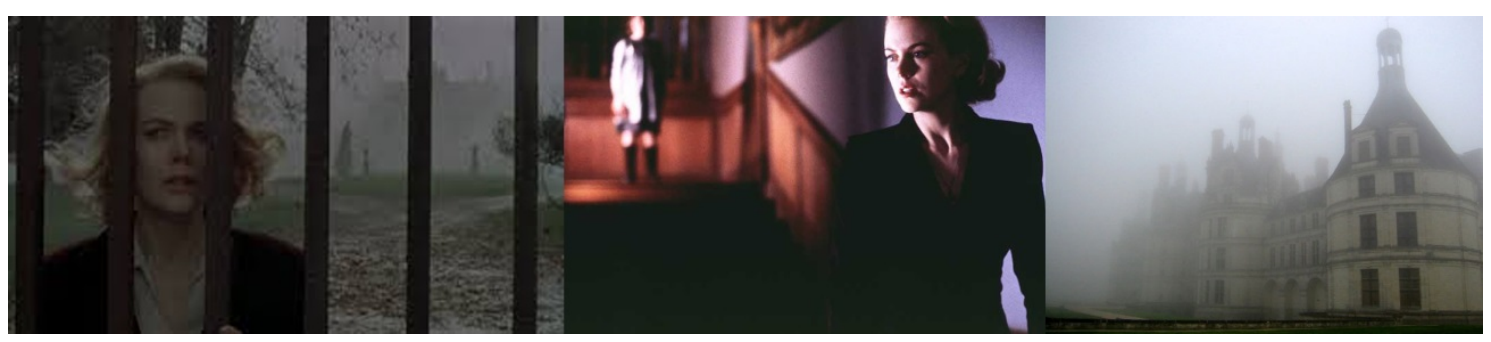

Şekil 1: The Others/ Diğerleri, 2001 (Url-1).

II. Dünya Savaşı sırasında büyük bir evde yaşayan aileye odaklanan filmde, izleyiciye ailenin evlerine nasıl kök saldığı, varlıkları ile evlerinin nasıl bir bütünlük taşıdığı vurgusu verilmeye çalışılmaktadır. Filmdeki anlatı çocukların güneşe duyarlı bir hastalığa sahip olmaları sebebiyle sürekli perdeler kapalı, kapılar kilitli (bir kapı kapanmadan diğer kapının açılmadığı) bir yaşam olarak aktarılmaktadır. Perdelerin kapalı tutulduğu karanlık odalar, uzun koridorlar, bir kapı kapanmadan diğer kapının açılmadığı kilitli kapılar gibi mekânsal görselleştirmeler ile ailenin yalnız, içe dönük yaşantısına tanıklık edilebilmektedir. Tanıdık/aşina olan ev mekânı ile oluşturulan tekinsizlik hissi ev halkının fiziki olarak kendi evleri ile kurdukları bağ üzerinden vurgulanmaktadır.

Genel kurgunun bilindik bir ev mekânı üzerinden gerçekleştiği bu filmde yönetmen, sisli bir peyzajın ortasında, kapalı perdeli, loş odalı bir malikâneyi ana mekân olarak belirlemiştir. Görsel betimleme tipik korku filmi göndermelerini içerirken, alt metindeki ev kavramı filmin temelindeki tekinsizlik hissini destekler niteliktedir. Filmdeki yaşantıyı Bachelard'ın "dünyadaki köşemiz" olarak tanımladığı ev ile bağdaştırmak mümkündür. Ona göre yaşamın tüm diyalektiği ile uyum içindeyizdir ve gün be gün dünyanın bir köşesine kök salarız (Bachelard, 2003, s. 34).

Bachelard'ın ev kavramı anılar ile bütünleşir. Ev sayesinde anılarımız yer bulur, mahzenden tavan arasına her bir noktada sığınaklar edinilir. İnsan zaman içinde yitip giden varlığını durdurmak isterken istikrar bulduğu mekânlarda saplanıp kalır (Bachelard, 2003, s. 39). Aynı zamanda Benjamin, bir mekânda yaşamayı orada izler bırakmak olarak tanımlarken, sahiplenilen mekânı bireyin yalnızca evreni değil, aynı zamanda da içinde her şeyini sakladığı kutusu olarak görür (Benjamin 1995, s. 98). Filmdeki karakterler de evlerini kendi varlıklarını zaman içerisinde sakladıkları sığınakları olarak görmektedir. Yalnız ve içe dönük yaşantılarında oraya ait olmamalarına rağmen ev dedikleri yere psikolojik olarak bağlı olmaları, o evde bulunan ve o evin asıl sahipleri olan başka insanları görmemelerine sebep olmaktadır. Yaşadıklarını düşündükleri eve ait olmadıklarını anlayınca yıkılan aile kendilerini umutsuz ve güvensiz hissetmeye başlamıştır. Filmin başında onlar için bir yuva olan ev artık onlar için tanımlanamaz ve hiçbir zaman ait olmadıkları tekinsiz bir yere dönüşmüştür.

Ev kavramı üzerinden oluşturulan tekinsizlik kurgusuna bir diğer örneği Türk sinemasından vermek mümkündür. 90'lı yıllara damga vuran yönetmen Zeki Demirkubuz'un sinemasında ev doğrudan tekinsiz, ürkütücü, geçmiş yaşantıların travmatik izleriyle dolu bir mekân olarak kurgulanmaktadır (Suner, 2005, s. 173). Yönetmenin filmlerinde mevcut yaşanan alanların içinde barındırdığı tekinsizlik söz konusudur. Demirkubuz'un filmlerinde "ev"in tekinsiz, ürkütücü, rahatsız edici bir yere dönüşmesinin nedeni büyük oranda yaratılan klostrofobik atmosfer olduğunu vurgulayan Suner (2003, s. 175), öykülerin ana mekânlarını oluşturan izbe otel odaları, 
kasvetli ev içleri, zevksiz ofis mekânları ile kapalılık duygusunun oluşturulduğunu aktarır.

Aydınlı (2008, s. 158) yaşamın işlevsel sürecinin mekânın fiziksel özellikleri ile ilgisi olduğunu, mekân kavramının da duygusal ve düşünsel davranış biçimleri ile yeni anlamlar kazandığını söyler. Anlam mekânın algılanma biçimi ile şekillenir. Neyi algıladığımız neyi bildiğimize dayanmaktadır diyen Roth (2006, s. 91) insan zihninin kendine gönderilen tüm duyumsal uyaranlarda anlam aramaya programlı olduğunu ve bunun da yaşamda kalma içgüdüsü ile bağlantılı olduğunu vurgular. Ona göre bilinç temelinde tanıdığımız şeyleri anlamlandırır, gelen veri anlamsız olduğunda bilinç bunu tanıyamaz. Freud'un yabancı ve bilinmedik değil, tersine aşina ve çok iyi bilinen, ancak bastırılma sonucu yabancılaşmış olan bir şeyle karşılaşıldığında insanlara dehşet, korku, ürperti hissi uyandıran şey olarak tanımladığı tekinsizlik kavramını bu anlam ve anlamlandırma süreçlerinin bir parçası olarak ele almak mümkündür.

$\mathrm{Bu}$ anlam ve anlamlandırma ara kesitinde gidip gelen C Blok filminde mekânsal tekinsizlik apartman blokları arasında bir dairede sıkışmış bir hayat üzerinden okunabilmektedir. Algı, anlam ve anlamlandırma üçgeninden filme bakıldığında yaşamda kalma içgüdüsü ile ev kavramının ilişkilendiğini söylenebilir. Filmde de aşina bir apartman dairesi izleyici ile buluşur. Dönemi yansıtan modern bir görünüme sahip olan ev ana karakter için kendisini güvende hissettiği bir yuvadan çok mutsuzluk ve huzursuzluk yaratmaktadır. Film git gide bu hissi izleyiciye de aktarır. Karakter var olma içgüdüsü ile evinden uzaklaşmakta evine yabancılaşmaktadır (Şekil 2).

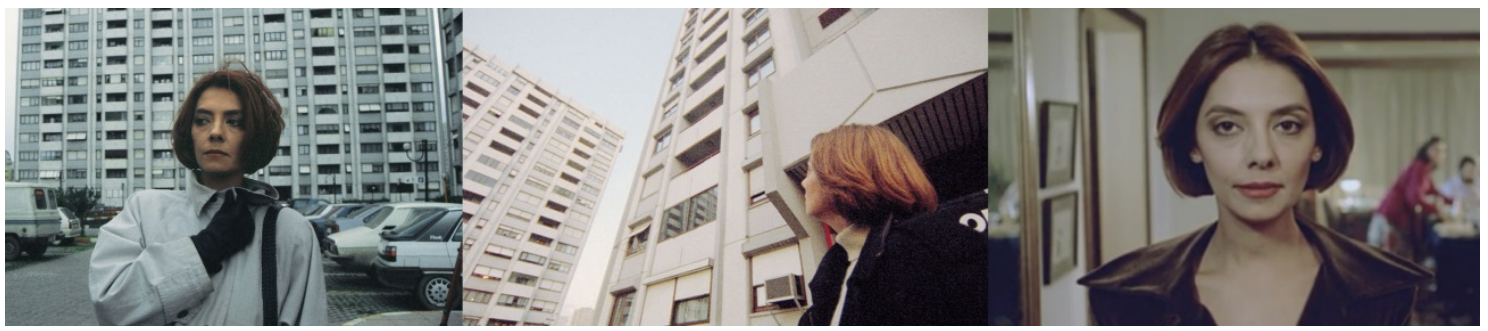

Şekil 2: C Blok, 1994 (Url-2).

Suner (2005, s. 174) C Blok filminin yönetmenin filmlerindeki evlerin hiçbir biçimde yabancı, yadırgatıcı, sıra dışı görünmediğini, aksine normal, sıradan, kendi halinde göründüklerini vurgular. Suner'in mahremiyet ile ilişkilendirdiği ev karakteri dışarıdaki tehditlerden koruyamaz hale gelir. Ev çaresizlik ve yalnızlık alanına evirilerek tekinsiz bir mekâna dönüşür.

\subsection{Bilinçaltı Mekânı; Labirent Çıkmazı-Tekrarın Tekinsizliği}

Freud'da göre, tekinsizlik hissinin kaynaklarından biri "istemsiz tekrar"dır (Suner, 2005 s. 183). Rüyalarda da sık sık karşılaşılan bir olgu olan kaybolma sonrası yolun tekrar tekrar aynı noktaya çıkması, gösterilen çaba sonrası tekrar aynı yere gelmek çaresizlik duygusunu yaratır (Freud, 2003, s. 144). Başka bir deyişle belli bir durumun istemsiz tekrarı tekinsizlik duygusunu yaratmaktadır. Tekrar öğesi, tekinsizlik hissi yaratmanın yanı sıra, kapalılık duygusunu da güçlendirir. Karakterler sanki ne yaparlarsa yapsınlar dışına çıkamayacakları bir labirentin içindedir. Kapalı bir dünyada her şey sonsuz bir döngüde kendini tekrarlar (Suner, 2005, s. 183).

Tekrar karşısında yaşanan tekinsizlik durumunu doğrudan bilinçaltımız ile ilişkilendirmek olasıdır. Tekinsizlik doğrudan bilinçaltımız üzerinden şekillenmekte, 
hayatta kalma- var olma içgüdüsü üzerinden de mekânsallaşmaktadır. Sinemada kullanılan kovalamacalar, tekrarlar, bir türlü içinden çıkılamayan labirent biçiminde mekanlar izleyicinin de varoluş duygusunu tetikleyici niteliklere sahiptir.

Stanley Kubrick'in Shining/Cinnet filmi de tekrarın ve çıkmazın oluşturduğu tekinsizliği otel mekânı üzerinden kurgulamaktadır. Filmde, Overlook Oteli, muazzam salonları, bu mekânlara açılan dar, uzun, labirentvari koridorları ile eski gotik filmlerin şatolarını akla getirirken, başkarakter Jack'in zihinsel bozukluğunun ortaya çıkmasında kötücül bir görev üstlenecek şekilde kişiselleştirilir. Kamera doğrudan insanın doğasına çevrilidir ve filmde insan ruhunun karanlık doğasında bir yolculuğa çıkar. Bu yolculuk, filmin ilk sahnesinden başlayarak otelin dolambaçlı koridorlarında devam edip otel bahçesindeki karlı labirente son bulur.

Filmde ana karakter Jack, Colorado dağlarındaki Overlook Oteli'nin bakıcısı olmayı kabul eder. Otel kışın kapalı kalacağından Jack ve ailesi uzun bir süre boyunca mekânın tek misafirleri olacaklardır. Kar fırtınası aileyi dış dünyadan yalıttığında, medyumluk ve telepatik güçlerden nasibini almış olan Jack'in oğlu Danny otelin "perili" olduğunu ve ruhların babası Jack'i yavaş yavaş çıldırma noktasına getirdiğini fark eder. Bir süre sonra hayatta kalmanın tek yolu filmin içindeki dar alanlardan kurtulmaktan geçer hale gelir. Çıldırmış babanın dehşeti, bir labirentte babanın ölümü ile son bulur. Film mekânsal çıkmazlardan oluşan bir kurgu içinde gerçekleşen kovalamacaların ne kadar dehşet verici olabileceğinin en iyi örneklerinden biridir (Şekil 3).

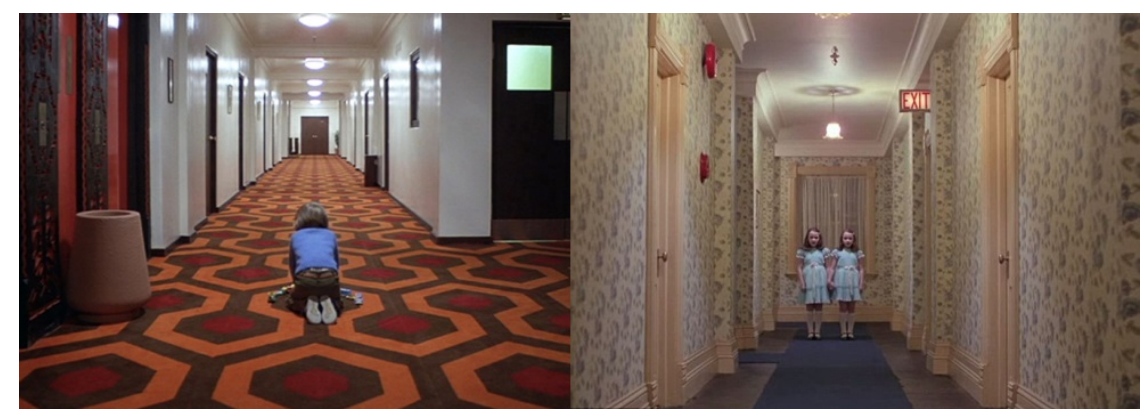

Şekil 3: Overlook Oteli labirentvari koridor sahneleri (Url-3).

Filmde koridorların labirentvari yapısı karakterin bilinçaltında gelişen olayların kurgusu gibidir. Çünkü labirentler tam bir kapalı mekân olmasalar bile, "dışına çıkılamaması" durumunda ölümcül olurlar ve labirentlerden korkulmasının ana sebebi bu durumun gerçekleşmesi intimalidir. Mekân kurgusu izleyicinin bilinçaltına göndermeler yaparak hem içeride kalmanın tekinsizliğini hem de dışarı çıkmanın imkânsızlığını sorgulatır niteliktedir.

İstemsiz tekrar ile oluşan tekinsizlik kavramına bilinçaltı korkularının ön plana çıktığı bir çeşit oyun formatıyla kurgulanan, düşsel bir durumu anlatan mekânlarıyla Cube/Küp, filmi örnek gösterilebilir. Filmde mekân küp şeklinde bir odadır (Şekil 4). Film karakterlerin kendilerini aniden içinde buldukları kübik bir mekânda başlar ve devam eder. Duvarlarda gökdelenlerin demir travers iskeletlerini ve elektronik aygıtların entegre devrelerini çağrıştıran figürler bezeli olan mekan modernizmi çağrıştıran bir dekorasyona sahiptir. Freud'un (2010) doğduğumuz günden beri en büyük emelimizin "anneye geri dönmek" olduğu savını düşündüğümüzde, filmdeki kübik mekânlar bilindik aşina olunan bir evden çok daha karanlık ve içine aldığında çok daha öldürücü olabilecek, tam olarak ana rahmine karşılık gelen mekânlar olarak nitelendirmek olasıdır. 


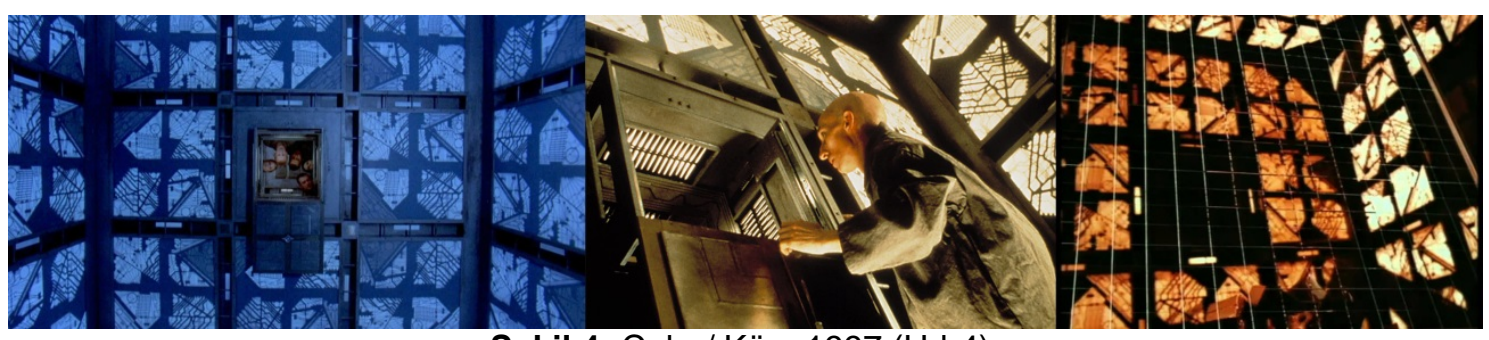

Şekil 4: Cube/ Küp, 1997 (Url-4).

Film boyunca karakterler görsel olarak aynı fakat tepkisel olarak değişen klostrofobik kübik mekânlar içinde hareket ederler ve her mekân filmin kurgusuna göre içinde bulunan kişiye farklı tepkiler vermektedir. Odanın altı çeperinde birer çıkış kapağı bulunmaktadır ve bu kapaktan aynı görüntüde bir başka mekâna geçilir. İç içe geçen bu küçük küpler aslında koca bir küpün parçalarıdır. Bir mekânda ayaklarınızın altındaki zemin bir diğerinde tavana dönüşebilmektedir. Böylece her ne kadar mekânlar birbirinin aynı gibi gözükse de diğer odada neyle karşılaşılacağı belirsizdir. Bu benzerlik ve belirsizlik durumunu Freud'un (2002) tekinsizliği belirsizin dehşet veren bir ruh hali olarak tanımlaması üzerinden okumak mümkündür. Filmdeki görece aynı ama içerik olarak farklı mekânların sürekli tekrarlar ile ortaya çıkması, tekrar eden bilindik bir mekânın belirsizliği ve bu durumun bir bekleyiş içinde dehşet vermesi Freud'un (2002, s. 271) bilinçaltında bastırılanların bilindik olanın belirsizliği ile geri dönmesiyle yüzeye çıkan korku ve kaygının oluşturduğu tekinsizlik tanımı üzerinden okunabilir.

Bu filmdeki mekânsal tekinsizlik ile oluşan "zihinsel belirsizlik", "yabancılık hissi", "ait hissetmeme" (Erdem, 2019, s. 80) durumu filmde mekânsal olarak karşımıza hareketle katedilen, keşfedilen, önümüzde açılan bir uzam olarak değil, tersine sürekli kendi üzerine kapanan, hareketi yutan bir labirent olarak çıkar. Mekânla hareketin koordinatları hiçbir zaman uyuşmaz. Her denemede karakterler iyice kapana kısılır ve tekrarlar arasında akıl sağlıklarını yitirmeye başlarlar. Tekinsizlik filmin ana merkezine oturur. Bu durumu davranış ve deneyim üzerinden ele almaya çalıştığımızda fenomenolojik yaklaşıma değinmek mümkündür. Wild'ın tanımı ile deneyimin özünü arayan fenomenoloji (1963, s. 20) günlük yaşamdaki düzenlerin arkasında yatan ilişkilerin açığa çıkmasını hedefler. Doğal düzen olarak tanımladıkları bu "pattern"örüntü-ler bilişsel şemalara dönüşerek zihinsel olarak haritalanabilmekte ve günlük hayatın içerisinde bireylerin deneyimlerini şekillendirebilmektedir (Seamon, 1980, s. 151).

Filmdeki tekrarların tekinsizlik oluşturmadaki bir diğer etkeni mekânın biçimsel olarak aynı kalmasına karşın sürekli değişmesi; karakterlerin de mekân içinden çıkmak için bir çözüm ürettiklerinde bir sonraki mekânda bu çözümün işe yaramamasıdır. Başka bir ifadeyle bir mekân için oluşturulan bilişsel şema biçimsel özelliklere sahip diğer mekâna uymamaktadır. Filmde de ana nokta parçası olduğu mekânın ve sistemin özne tarafından "haritalanamaması"dır. Filmde oluşturulan mekânsal paradoks her mekânın hem aşina hem de oldukça yabancı gelmesi üzerinden kurgulanmıştır. Bu karmaşa izleyici için de zihinsel bir kayboluşa neden olup tedirginlik duygusunun oluşmasına neden olmaktadır.

\subsection{Bilinçaltı ve Bilinçdışının Kesiştiği "Tekinsiz" Mekânlar- Varoluşsal Mekânlar}

Bilinçli zihin, zihnin eylemleri ile duygularının farkında olan bölümüdür. Bilinçdışı, zihnin ve kişiliğin farkında olunmayan yönlerini kapsar (Snowden, 2010, s. xxvı). Hem kendi hem de hastalarının rüyalarıyla sistematik bir biçimde çalışan Freud, rüyalar ile 
bilinçdışı düşlemler arasındaki ilişkinin önemi üzerine durmuştur. Bastırılmış duyguların genelde rüya esnasında kılık değiştirerek yüzeye çıktığını ve anımsanan rüyaların bu gömülmüş duyguları gün yüzüne çıkarmaya yardımcı olabileceği düşüncesinin altını çizmiştir. Bu noktada bilinçli olunan anlarda varlığımızın farkındalığı ile kendini gösterirken, uykudayken bilincimiz kaybolur, dolayısıyla rüyada yaşadıklarımızı kontrol edemeyiz. Freud' a göre (1999, s. 9) görülen bilinç hallerinin gerisinde çok daha derinde ve görünmez bir bölgede işleyen başka bir yapısı daha söz konusudur. Bu bölgenin adı bilinç dışıdır ve bilinç durumunu etkileyen asıl olarak bu yapıdır.

Bilinç, bilinçaltı ve tedirginlik kavramları sinema mekânlarında doğrudan ya da dolaylı anlatımlarda yer alırken insan zihnini mekân edinen filmlerde de kimlik kavramı üzerinden bir tekinsizlik vurgusu göze çarpmaktadır. İnsan zihni gerek doğrudan ("John Malkoviç Olmak" filmi/ Being John Malkovich) ya da dolaylı bir içimde rüya mekanizması üzerinden ("Hücre" filmi/ The Cell) sinemasal mekâna dönüşerek izleyiciye tekinsizlik duygusunu yansıtır. Her iki filmde de kişinin varoluşunu deneyimleyebildiği bilinçli olma hali başkaları tarafından manipüle edilmekte bir nevi kişinin bilinçdışı üzerinden tekinsiz mekânlar kurgusu izleyiciye ulaşabilmektedir.

Afişinde de "Ever wanted to be someone else?" (Hiç bir başkası olmak istedin mi?) sorusu yer alan John Malkoviç Olmak filminde (Şekil 5) insan bilinci kurgulanan bir 7.5. kat kavramı üzerinden mekânsallaşır. Klostrofobik atmosferde açılan bir kapıdan, gerçek üstü bir uzaya, insan zihnine geçiş yapılır. Karakterler 15 dakika boyunca ünlü oyuncu John Malkoviç'in zihninin içinde var olabilmekte; onu, ona fark ettirmeden kontrol edip dış dünyada John Malkoviç olmayı deneyimleyebilmektedirler. Her deneyim sonrasında kendileri mi yoksa John Malkoviç mi olduklarını/olmak istediklerini sorguladıkları bir sürece giren karakterler üzerinden bilinç, bilinçdışı ya da bilinçaltı kavramlarının birbirine girdiği gözlemlenebilmektedir
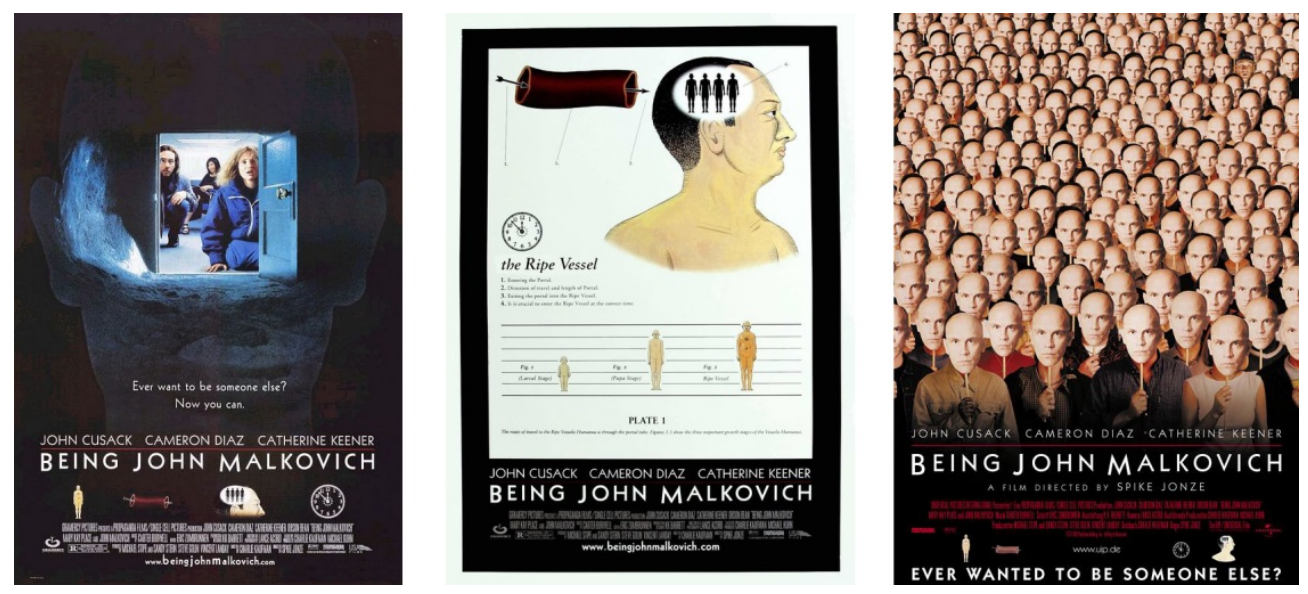

Şekil 5: John Malkoviç Olmak (Being John Malkovich) film afişleri (Url-5).

Filmdeki 7,5. kat doğrudan bilinçaltına gönderme niteliği taşımaktadır (Şekil 6). 7. ve 8. katlar arasındaki bu alan düşsel bir hikâye ile geometrik ya da orantısal kaygıların, güven duyma, rahatlık ve korunma gibi psikolojik gereksinimlerin mekânı biçimlendirmesinin yanında mekânın metafiziksel boyutuna da atıfta bulunmaktadır (Şahin ve Allmer, 2010, s. 85). Üç boyut anlayışının dışında olan bu kat, biçimsel açıdan da bir insanın başka bir insanın zihni/bilinci içine sığmasına/sıkışmasına bir gönderme niteliği taşımaktadır. 


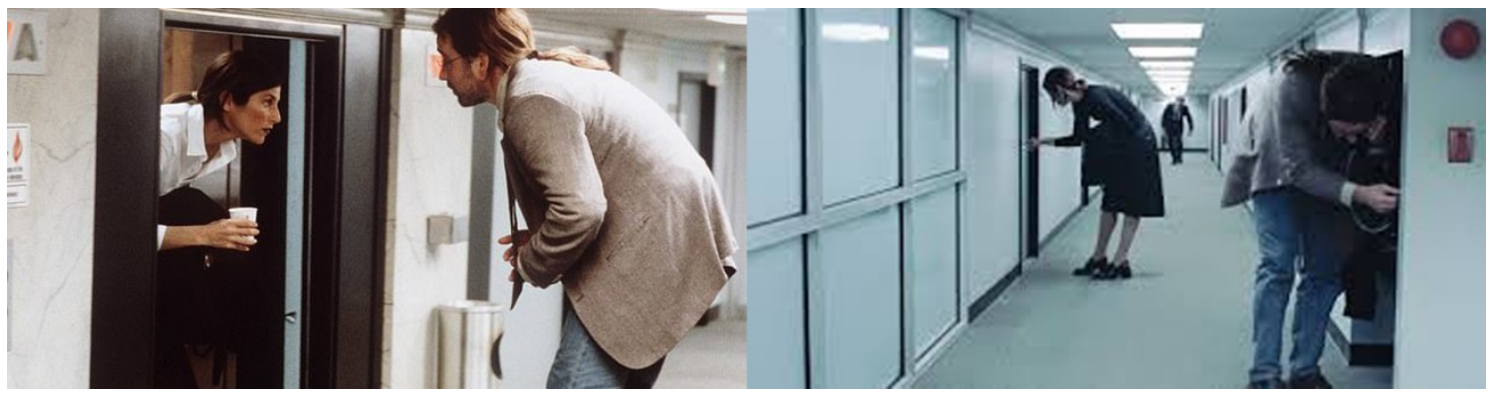

Şekil 6: 7.5. kat, John Malkoviç Olmak (Being John Malkovich) (Url-6).

Ana karakter Craig, "bilinç korkunç bir lanet, düşünüyorum, hissediyorum, acı çekiyorum" der. Malkoviç'in zihnine her girdiğinde ise tamamen başka bir zihin içinde başka bir bedeni deneyimleyerek sorumluluktan kurtulur, başka birinin bilinci içinde kendi bilinçaltını serbest bırakarak 15 dakikalığına yeni bir varoluşa sahip olur. Bunlar olurken John Malkoviç kendi varoluşunun aşinalığı içinde tekinsizlik hissetmeye başlar. Anlamlandıramadığı durumlar ile hem kendisi hem de içerideki kişiler üzerinden bilinç, bilinçdışı kavramları arasında gidip gelen varoluşsal bir tekinsizlik ortaya çıkar.

Bilinç kavramının subjektif yapısını mekânlar aracılığıyla kullanan sinema mekânlarına bakıldığında insan zihninin deneyimlenen mekân haline geldiği örneklerden bir diğeri olarak Cell/Hücre filmi ele alınabilir. Filmde insan zinninin karmaşık yapısı ve imgelem gücü rüyalar üzerinden üç boyut kazanarak perdeye yansır (Şekil 7). Yaşananı fark edebilme yeteneği doğrultusunda, izleyerek, değerlendirerek, karar vererek ve çevreye karşı tavır koyarak öznel olarak kendinin farkında olma ve kendini birey olarak algılayabilme durumu olarak tanımlanabilen bilinç kavramı filmin ana ekseninde yer almaktadır.

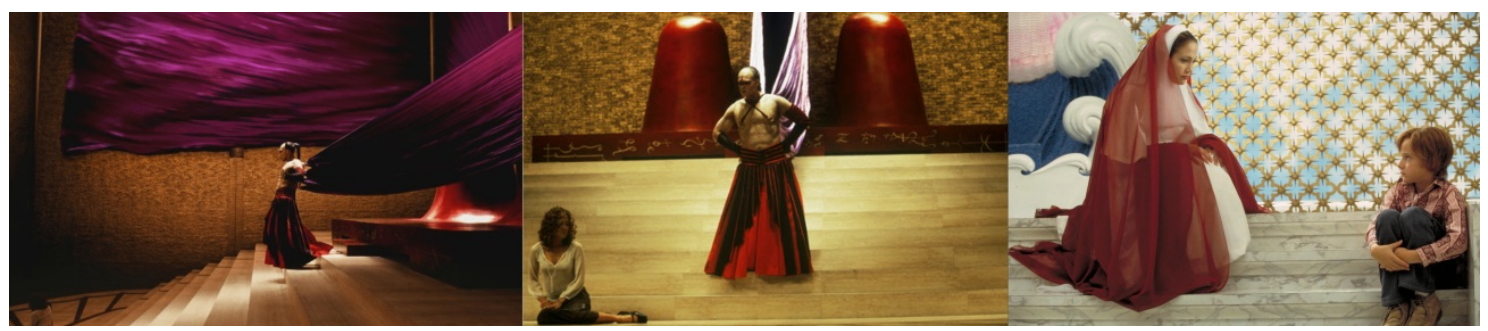

Şekil 7: The Cell / Hücre filminden iç mekân çekimleri (Url-7).

Film, bir seri katilin aklının karanlık ve tehlikeli köşelerinde ilgi çekici ve şok edici bir zihin yolculuğu yapar. Katilin tuzağa düşürdüğü fakat hala yaşamakta olan son kurbanını kurtarmak için gerekli anahtar bu aklın içindedir. Bilim-Kurgu gerilim türünde yeni ve keskin bir yönelimle film, olağan üstü bir hayal gücüyle, deli bir adamın içindeki en kutsal yerin kapısını yerle bir ederek açar. Bir diğer deyişle katilin "kendi evi"nin içine girer. Filmde kaçırılan bir kızın yerini tespit etmek için bilinçli bir şekilde bir katilin bilinçdışına girilir. Fakat bu işlem gerçekleştiğinde katilin bilinçdışına giren kişinin dışarıdaki gerçekliğin varlığını unutup bilinçdışının gerçekliğini kendi gerçekliği olarak kabul edebilme riski söz konusudur.

Filmde görülen mekânlarda da sürekli bu ikilem hissedilmektedir. Hangisi kimin bilinç dışı, kimin gerçekliği? Sürekli bir gerçeklik sorgusu söz konusudur. Ama kimin gerçekliği olduğu bir süre sonra ayırt edilemez. Normal yaşamda kullanılan ölçeklerin 2-3 katı boyutundaki mekânlar, ya da daha derin dar kapalı alanlar arasında geçen bu 
film insan zihninin içini mekânsallaştırma adına önemli bir örnektir. Her iki filmde bilinç kavramını doğrudan insan zihnini mekânsallaştırarak ele almakta ve mimari mekân üzerinden tekinsizlik kavramını görselleştirmektedir.

Bilim kurgu, korku, gerilim türü filmlerde öykülerin bilinç ve bilinçdışı algılama üzerine kurulması sonucu ortaya çıkan mekânlar tekinsiz olmalarının yanı sıra her zaman merak uyandırıcıdır. Tıpkı bir rüyanın parçaları gibi gözüken bu tür filmlerde kullanılan mekânlarda çeşitli imgelerden yararlanıımıştır. Mekânsal imge oluşumu ve değişimi algılamayı oluşturan fiziksel ve zihinsel tüm duyum ve duygulanımlarımızdan etkilenmektedir.

Mekânı deneyimleyen insanın zihninde oluşan yansımaların tümü olarak tanımlanabilecek olan mekânsal imge sinemanın en temel unsurudur. Filmlerde sinemasal anlatı iki boyutlu düzlem üzerinde karşımıza çıksa da üçüncü boyutta mekânsal ve psikolojik algıları zorlayan birçok örnekte mekânsal imgeler oldukça sık kullanır. Söz konusu filmlerde özel tasarımlı "mekânların tekinsizlik hissi yaratması, perspektif, ışık-gölge gibi görsel unsurların yanı sıra, kamera kaydırmaları, hareket, süreklilik, kurgu, fon müziği gibi sinematografik yöntemler aracılığıyla sağlanır. Algısal psikolojiye ait gestalt ilkeleri, her sahnenin istenen mesajı verecek şekilde algılanmasında devreye girer ve seyircinin "mekân deneyimi" simülasyonuna işlerlik kazandırır. Bu noktada "tasarlanan mekân", filmin atmosferini ve biçemini belirlemede filmin oyuncusu gibi işlev görür.

\section{SONUÇ}

İnsan mekânla var olur ve kendini mekânsız düşleyemez. Sinema da görsellik üzerine kurulu olması ve insan üzerinden şekillenen yapısı nedeniyle mekânı kullanmaya muhtaçtır. Mekânların tasarlanması ya da düzenlenmesi söz konusu olduğunda kuşkusuz sinema gerçek mimari mekânlardan daha özgür alanlar sunmaktadır. Sinemada kullanılan mekânlar ister bir oda, ister bir şehir, isterse insan zihninin içi olsun mekânı kullanım şekli ile düşsel bir gerçekliğin oluşmasına olanak tanır. Yaratılan bu düşsel gerçeklik ile anlatılmak istenen hikâye mekânlar aracılığı ile yepyeni bir deneyimin ara kesitini sunabilmektedir.

Sinemasal mekânda mekân sadece fiziksel dünyanı bir parçası değil, zihinselliğin, düşselliğin, içselliğin de bir parçasıdır. Mekân sadece barınmak için var edilmiş bir fiziksel gerçeklikten ziyade, düşünceden doğan, hissedilen, bilinçaltında yer eden, var olan bir mekâna dönüşür. Tekinsizlik kavramı, sinemada kullandığı mekânsal özelliklerle, dikkatimizi dışarı, yani kendimize çevirebilmektedir. Sinema aracılığıyla mimari mekân sadece bir yapı parçası değil, insana özgü duyguların, algıların, değerlerin, beğenilerin, deneyimlerin yansıdığı yaşayan bir atmosfer olarak karşımıza çıkmaktadır.

Kurgulanan sinemasal mekânlar ile mimarlığın sanatsal değeri somut olarak varlığında değil, gözlemcide (bilinçaltında, bilincinde) uyandırdığı hayallerde ve duygularda yer bulmasına olanak sağlamaktadır. Sinemasal mimari deneyim bu bağlamda kendimizin deneyimine dönüşebilmektedir. Zihinde başlayan bir süreç olan mimarlık eylemi de tıpkı sinema gibi, takip eden tüm evrelerinde görüntülerle düşünmeyi ve zihinsel mekân kurgularının imgelenme biçimleri üzerinden şekillenmektedir. $\mathrm{Bu}$ bağlamda da kurgulanan mekâna bilinç, bilinçaltı ve bilinçdışı kavramları üzerinden bakmak yeni bir mekân okumasına olanak sağlamaktadır. Yaklaşılan yeni okuma biçimleri ile de mimari mekân üretimi üzerine yeni söylemler üretmek mümkün halde gelmektedir. 


\section{KAYNAKLAR}

Aydınlı, Semra, "Mekan"dan "Mekansal"a:Mekanın Zamansallığı/ Zamanın Mekansallığı. Şentürk, A.,Ural, Ş., Berber, Ö., ve Sönmez, F. U. (Editörler) ZamanMekan (150-161). İstanbul:YEM Yayın. 2008.

Aytaç, Ömer, Bilincin Sosyolojik Analizi. Elektronik Sosyal Bilimler Dergisi. 2003; 2(4).

Bachelard, Gaston, Mekânın Poetikası (La Poetique de l'espace), İthaki Yayınları, 2003.

Benjamin, Walter, Pasajlar. İstanbul: Yapı Kredi Yayınları.1995.

Beşışık, Gökçe, "Sinema ve Mimarlıkta Mekân Kurgusu ve Kavrayışı." Yayınlanmamış Yüksek Lisans Tezi, Dokuz Eylül Üniversitesi, İzmir 2013.

Bruno, Frank.J., Adjustment and Personal Growth: Seven Pathways, NewYork Wiley, 1982.

Enç, Mithat, Ruhbilim Terimleri Sözlüğü, Türk Dil Kurumu, 1974.

Erdem Kaya, Burcu, "Freudyen Teorideki "Tekinsizlik" Olgusunun Türk Modernleşmesinde Darbeleri Mümkün Kılan Obskürantist ve Self-Oryantalist Tutumlarla Ilişkiselliği Üzerinden Okunması." Türkiye İletişim Araştırmaları Dergisi 32: 77-97. 2019.

Freud, Sigmund, The Uncanny. Penguin, 2003.

Freud, Sigmund, Psikanaliz Üzerine (Çev: A. Avni Öneş). İstanbul Say Yayınları, 2010.

Freud, Sigmund, Metapsikoloji. E. Kapkın ve A. Tekşen Kapkın (Çev.). İstanbul: Payel Yayınları, 2002.

Heidegger, Martin, Being and Time, Çev. Joan Stambaugh, Suny Press, Albany, (1927) 1996.

Kılıç, Onur, Korku Sinemasının lç Mekân Tercihlerine Bir Bakış, Akademik Sosyal Araştırmalar Dergisi, Yıl: 5, Sayı: 54, Ekim 2017, s. 428-432.

Ornstein, Robert, Yeni Bir Psikoloji, çev. Erol Göka-Feray Işık, İstanbul: İnsan Yayınları, 1990.

Merleau-Ponty, Maurice. Phenomenology of Perception [Phénoménologie de la Perception]. Routledge \& Kegan Paul, 1962.

Roth, Leland, M., Mimarlığın Öyküsü, Ögeleri ve Anlamı (Çev. Ergün Akça). İstanbul: Kabalcı Yayınevi.- 2006.

Seamon, David, "Body-subject, Time-Space Routines, and Place-Ballets." The Human Experience of Space and Place 148 (1980): 65.

Shaffer, Jerome A. ve Turan Koç, Zihin Felsefesi Açısından Bilinç, Ruh ve Ötesi. İz Yayıncılık, 1991. 
Snowden, Ruth, Freud: Kilit fikirler. Optimist Yayınları, 2012.

Suner, Asuman, "Hayalet Ev: Yeni Türk Sinemasında Aidiyet, Kimlik ve Bellek." Metis Yayınları, 2005.

Şahin, Zümrüt ve Allmer, Açelya, "Beden, Mekân ve John Malkovich Olmak", Sinemekan, Sinemada Mimarlık, Varlık Yayınları, 2010.

Url-1 <https://www.imdb.com/title/tt0230600/mediaindex?ref_=tt_pv_mi_sm>, erişim tarihi 07.10.2019.

Url-2 <https://sanatlakalalim.wordpress.com/2017/08/23/bir-arayis-cabasi-c-blok/>, erişim tarihi 07.10.2019.

Url-3 <https://www.imdb.com/title/tt0081505/mediaindex?ref_=tt_pv_mi_sm>, erişim tarihi 09.10.2019.

Url-4 <https://www.imdb.com/title/tt0123755/mediaindex?ref_=tt_pv_mi_sm> erişim tarihi 11.10.2019.

Url-5 <https://www.imdb.com/title/tt0120601/mediaindex?ref_=tt_pv_mi_sm> erişim tarihi 11.10.2019.

Url-6 <https://www.imdb.com/title/tt0120601/mediaindex?ref_=tt_pv_mi_sm> erişim tarihi 11.10.2019.

Url-7 <https://www.imdb.com/title/tt0209958/mediaindex?ref_=tt_pv_mi_sm> erişim tarihi 10.10.2019.

Wild, John, Existence and the World of Freedom, Englewood Cliffs, NJ- Prentice Hall, 1963.

Zijderveld, Anton C., Soyut Toplum. Pınar Yayınları, 1985. 